\title{
Effectiveness of Local History Module Based on Inquiry to Improve the Learning Achievement of High School Students
}

\author{
Mela Mita Septiana, Nunuk Suryani, Akhmad Arif Musadad \\ Sebelas Maret University, Surakarta \\ mella_meta@yahoo.com
}

\begin{abstract}
The learning process is a process of communication which means the process of delivering a message from a resourcer to the receiver. Media is the part of the communication process because basically learning is a process of communication. Learning media in the form of a module is a supporting device to improve student's achievement. This study aims to determine the effectiveness of historical learning by using local history module to improve the student's achievement in senior high school on the historical material of the struggle to defend freedom. The study population was all social science students of class XII academic year 2015/2016. The research design was the group design of pre-test and post-test. The sampling technique used is cluster random sampling, obtained that class XII of Social Science 1 as an experimental class and class XII of Social Science 4 as the controlled class. The results showed the post-test average value of students' achievement on an experimental class at 79,64 and 76,78 for the controlled classes. Based on the results of this research, it can be concluded that the application of local history module proved effectively in improving the students achievement.
\end{abstract}

Keywords: local history module, learning achievement

\begin{abstract}
Abstrak: Proses pembelajaran merupakan proses komunikasi yang berarti adanya proses penyampaian pesan dari seseorang narasumbr kepada penerima pesan. Media merupakan bagian dari proses komunikasi, karena pada dasarnya pembelajaran merupakan proses komunikasi. Media pembelajaran berupa modul sebagai pendukung untuk meningkatkan prestasi belajar siswa. Penelitian ini bertujuan untuk mengetahui efektivitas pembelajaran sejarah dengan menggunakan modul sejarah lokal terhadap peningkatan prestasi belajar siswa pada salah satu SMA pada materi sejarah perjuangan mempertahankan kemerdekaan. Populasi penelitian ini adalah seluruh siswa kelas XII IPS tahun ajaran 2015/2016. Desain penelitian yang digunakan adalah pretest dan postest group design. Teknik sampling yang digunakan yaitu cluster random sampling, diperoleh kelas XII IPS 1 sebagai kelas eksperimen dan kelas XII IPS 4 sebagai kelas kontrol. Hasil penelitian menunjukan rata-rata nilai posttest prestasi belajar siswa kelas eksperimen sebesar 79,64 dan kelas kontrol sebesar 76,78. Berdasarkan hasil penelitian dapat disimpulkan bahwa penerapan modul sejarah lokal terbukti efektif dalam meningkatkan prestasi belajar siswa.
\end{abstract}

Kata kunci: modul sejarah lokal, prestasi belajar

\section{INTRODUCTION}

Historical learning is a subject taught at the level of Junior High School contained in a group of social science subject. However, history includes its own subject at the Senior High School level. Before further discussion about historical learning, learning is defined as an effort that affects someone's emotional, intellectual, and spiritual to learn on its own desire (Nata, 2009, p.85). While there are two actions in learning, the first is done by learners and the second is teaching done by educators. The essential purpose of learning is a changing in learners' behavior in the field of cognitive, affective, and psychomotor (Agung and Wahyuni, 2013, p.5), so it can be concluded that learning is a process of delivering knowledge to someone who aims to provide the behavioral changing in attitude, academic ability, and skills.

The historical learning in schools aims to enable students acquires the ability to think and 
understand historically. Through the historical learning, students enable to develop competencies for thinking chronologically and having knowledge of the past that can be used to understand and explain the development process and society changing as well as the diversity of social and culture in order to discover and foster the national pride in the midst of the world community life. The purpose of historical teaching is to instill the spirit of patriotism, to know the forming process of Indonesia, to increase the sense of unity for learners, and to know the process of Indonesia human civilization in particular and the world community in general from the first period to the present (Agung, 2012, p. 417).

The process of historical teaching implemented at school so far still uses the conventional learning method, teachers use monotonous lecturing method. The learning process is still poorly understood by students when the teacher is delivering the material to the students, so it results in the low achievement in learning and far from the high achievement as expected. At the conventional teaching methods, teacher predominates the learning (teacher center) and gives little opportunities for students to participate actively in learning.

The result of observation in SMA Muhammadiyah 1 Muntilan through the interviews' results with students is that learning in the classroom still uses the lecturing method, besides the lecturing method, teachers have not used the learning media optimally. The teaching materials mainly used by the teachers in the learning process are textbooks and a material summary prepared by the subject teachers. The average students' achievement is not maximal and it is not in accordance with the expected target. The using of learning media to support the learning process is still minimal. Seeing the lack of available facilities in each classroom, so the using of learning media is rarely used especially audio-visual media because there are some classes that are not equipped with an LCD projector.

The using of learning media as a supporting learning media to students in learning will be followed. As the opinions of Heinich, Molenda, and Russel in Lamatenggo and Hamzah (2011) states that "the technology or learning media as the application of scientific learning process on humans in the practical task of learning". In line with these opinions, Miarso (2004, p.456) states that "learning media is anything that is used to deliver messages and be able to stimulate the mind, feelings, concerns, and the willingness of the learners to learn so it can encourage the learning process ". Then it can be concluded that the learning media is a tool to facilitate the learning process which is done deliberately in order to achieve a goal of learning.

The lack of learning media usage and conventional learning methods affect student achievement levels. The low student achievement especially on the historical subject of which is a theoretical lesson, so it would require an innovation by improving the learning with utilizing the learning media and using the methods of historical learning adjusted to the current learning progress.

The using of learning media in the learning process can raise the desire and interest. As Hamalik opinion (1986) that the using of learning media in teaching and learning process can raise the desire and new interests, encourage motivation and learning stimulation activities and can bring the psychological effects on students. Meanwhile, according to Kustandi and Sucipto (2011, p 21), learning media can also help improve the understanding, present the data attractively, facilitate the data interpretation, expand the information, and raise the motivation and interest of students in learning. It can be drawn a conclusion that learning media can increase the interest and motivation of learners in learning.

There are some types of media that can be used in learning activities at school. According to Bretz (1971) divides the types of media based on three main elements, namely sound, visual, and motion. Bretz classified these three elements into eight groups, namely: (1) audio media, (2) print media, (3) silent visual media, (4) motion visual media, (5) semi-motion audio media, (6) semi-motion media, (7) audio-visual media, and (8) audio-visual motion media. Meanwhile, according to Ahmad (2007, p.31) states that there are three types of media that can be used in learning activities by teachers in schools, namely: (1) visual media is media that can be viewed using the sense of vision consists of media that can be projected and media that cannot be projected; (2) The audio media is media that consists messages in auditory form that can stimulate the mind, feelings, concerns, wishes the students to study the teaching materials and its kind; (3) audio-visual media is a combination of audio media and audio-visual media or the media point of view heard.

As the opinion stated that learning media have different kinds of stuff, and the essence-function of the media is to motivate interest, present information. Because every learning media has the ability, so the using of learning media in teaching and learning is 
adjusted to the needs at the school. It is expected that media becomes a tool that can accelerate or facilitate the achievement of learning objectives.

Based on the research in SMA Muhammadiyah 1 Muntilan on the historical subject, teachers only used the learning resources like textbooks. While the supporting learning resources such as learning media is not used maximally. The historical scores of students are low, while the students' historical knowledge is also lack. The low historical achievement of students was proved through the score of the daily test under the criteria of mastery learning, while the poor knowledge of students about local area's history is evidenced by interviewing the students.

Based on these results, we need a media that can improve the learning achievement and knowledge of local history. It is also required a learning model that can provide opportunities for student involvement in learning to be more active, watch the learning methods are still using conventional methods. The media used in the study is in the form of learning media-type of print media. Using print media based on the needs of historical learning in SMA Muhammadiyah 1 Muntilan. Print modules are intended to give students' motivation.

The definition of modules in the book of General Guidelines for Development of Instructional Materials (2004) that the module is a book written with the intention that the students can learn independently without a teacher or guidance. As another sense that the module is interpreted as a set of teaching materials are presented in a systematic, so that the user can study with or without a facilitator or teacher (Prastowo, 2011, p.104).

Therefore, a module should be used as teaching materials for substitute educator function. If an educator is able to explain something, then the module should be able to explain things in a language that can be accepted by learners in accordance with the level of knowledge and age. So the local history module that will be used in the teaching of history is able to explain the national historical events and $\mathrm{f}$ local history in a language that is easily understood by learners. Local history itself can be regarded as a form of historical writing of limited scope that covers a particular locality (Widja, 1989, p.13). The study of local history closes to the relation to oral and written tradition in the community. So that local history is very useful for historical knowledge learners because its own local history intertwined with national history. Indonesia history is national history that covers the entire era of the nation and the entire region in parts of the country.

Through the using of media learning, the local history module is expected to be a more effective learning than conventional learning methods commonly applied by teachers so it can improve student achievement. Inquiry learning model as a learning model will be applied in the learning process. As the opinion of Indrawati in Trianto (2009, p.165) states that a study will generally be more effective when conducted through the models of learning. This is because the learning model emphasizes a person to think and process information. According to Joyce and Weil (1980, p.107) that the essence of good thinking is the ability to solve the problem, while the base of the solution is the ability to learn in the process of thinking.

The discovery learning is part of the inquiry, or inquiry in the expansion discovery process that is used more deeply (Suryosubroto, 2009, p.193). The meaning of inquiry in English is question or examination, investigation. The inquiry is a general process by humans to find or understand information. Gulo (2002) states that the inquiry strategy is a series of learning activities that involve maximally throughout the student's ability to search and investigate in a systematic, critical, logical, analytical so that learners can formulate their own findings with confidence.

Meanwhile, according to Trianto (2009) states that the main target of inquiry learning activities are: (1) The maximum student involvement in the process of learning; (2) directed activities in logical and systematic to the learning objectives; and (3) a trust attitude development in students about what was found in the Inquiry process. Some of the opinions above, it can be concluded that inquiry learning can maximize the ability of critical, logical, analytical thinking of students as well as the level of thinking the development of students at the high school level. As a historical module which is implemented through inquiry learning model is expected to encourage students to explore the knowledge of history by processing the information as much as possible.

Based on the presentation above, the problem formulation in this study is whether the application of local history module based on inquiry is effective in improving student achievement in the historical material of the struggle of the youth in maintaining independence. The purpose of this study is to determine the effectiveness of local history module to improve the historical learning achievement 
of class XII students in SMA Muhammadiyah 1 Muntilan IPS.

\section{METHOD}

This research used a quasi-experimental with the using of pre-test and post-test design as research design. Quasi-experimental is defined as an experiment that has treatment, the impact measurement, experimental unit but the using of random assignment to create a comparison in order to conclude the changes caused by treatment (Cook and Campbell, 1979). The study population was the high school students in Muhammadiyah 1 Muntilan class XII of Social Science 1 as an experimental class and class XII of Social Science 4 as the controlled class by the number of students are 32 students in each class, who were taken by purposive sampling technique.

The free variable in this research is inquirybased of local history module for experimental class, and conventional learning models for the controlled class. The dependent variable in this study is the students' achievement of class XII of Social Science in SMA Muhammadiyah 1 Muntilan.

The method of data collection is conducted with test method, observation method, the documentation and questionnaires method. The test method was used to determine the level of student achievement, observation sheet was used to determine how much students 'knowledge of local history, and the questionnaire was used to determine the interest level of students' toward applied learning media.

The research data of achievement test was statistically analyzed and calculated by $t$ test, found the influence between variables to determine whether there was influence of the implementation of local history module inquiry-based that given by the researcher. The normalized gain test against the pre-test and post-test learning achievement were calculated to determine the improvement after being given a different treatment.

\section{RESULT AND DISCUSSION}

\section{The Local History Module of Inquiry-Based}

The supporting means in a learning is learning media, media has a variety of forms both packaged in the form of print and non-print. In connection with this research, local history module as a learning print media is used to improve the students' achievement in high school. The module is a teaching material which is systematically arranged in an easy language understood by students to learn independently (Prastowo, 2012, p.106). From these opinions, it can be concluded that the learning media as a means to achieve the learning objectives, as well as the modules are arranged in an easily understood in order to facilitate the learning.

Lack of students knowledge about local history obtained from the interview, due to lack of material used by teachers related to local history. Historical learning focused on one teaching materials textbooks so students only learn the material that already exists in the text book. Local historical materials that should be taught to students do not get a place in the delivering of teaching materials, although local history also includes as a part of national history.

Use of local historical modules tested to students class XII, while the learning process will use inquiry learning model. Inquiry learning model is a series of learning activities that emphasize critical thinking and analytical process to search and find their own answer to the problem in question (Sanjaya, 2006, p.196). There are some things that the main characteristic of inquiry learning. First, inquiry learning emphasize students optimally to find, means inquiry lies students as study subject. Secondly, the activities was carried by students directed to find their own answers to face the problems. Third, inquiry learning develop systematic thinking ability, logical, critical, or develop intellectual abilities as part of mental process. Mental development (intellectual) according to Piaget (1971) is influenced by four factors, they are maturation, physical experience, social experience, and equilibration. Masturation or maturity is a process of physiological and anatomical changes, the process of physical changes and anatomic, it is pyshical changing process. Physical experience, physical actions by individuals against existing objects in its environment.a. Social experience, activity in dealing with others. Equilibration, is the adjustment process between existing knowledge with new discovered knowledge.

The main objective of inquiry learning is encourage students to develop intellectual discipline and thinking skills by providing questions and get answers on the basis of their curiosity. Implementation of inquiry learning model in the learning process is expected to engage students actively inlearning, because the inquiry model is a form of learningoriented approach to students (student centered approach). Inthis learning studentshold a very dominant role in the learning process.

Local history module that will be used to 
take material with theme the struggle of Magelang youth against Japan in 1945. In 1945 the national history of the events of youth resistance against the invaders in the various regions. One of them is the youth resistance against Japan in 1945 which is one of the historical events that occurred in Magelang. Local historical materials is expected to increase the knowledge of local history and enhance the learning achievement of the students.

The inquiry learning steps consists of six stages as proposed by Eggen and Kauchak (1996), As follows: orientation, define problems, propose a hypothesis, collect data, test hypotheses, and drawing conclusions. The first phase, teachers guide students to identify problems and write it on the blackboard, the teacher divides the students into groups. The second phase, teachers provide students the opportunities to express opinions in the form of a hypothesis. Teachers guide students in setting hypotheses relevant to the problems and prioritize which hypothesis is a priority investigation. The third phase, the teacher gives students the opportunity to determine the suitable measures with the hypothesis that will be done. teachers guide students to arrange the experiment steps. The fourth phase, teachers guide students to get information through the trial. The fifth phase, the teacher gives each group the opportunity to present the results of processing data collected.. The sixth phase, teachers guide students in making conclusions.

\section{Implementation Module in History Learning}

Research will be conducted on social sciences students of class XII , students academic ability in each class is heterogeneous so the students population number who have the capability of high, medium, and low in every class are almost same. Sampling was done by purposive sampling, it is sampling technique based on a particular determination consider to the characteristics or properties of the previously known populations. based on this technique, it is defined two classes that the research sample is class XII IPS 1 as a class experiment that uses inquiry-based local historical module and class XII IPS 4 as the control class without using local historical module.

The research method used is quasi-experimental with Non-Equivalen Design group control. According to Creswell (2010) The method has a design as shown in
Table 1. Research Design

\begin{tabular}{lccc}
\hline \multicolumn{1}{c}{ Class } & Pre-test & treat & Post-test \\
\hline Eksperimental & $\mathrm{O}_{1}$ & $\mathrm{X}$ & $\mathrm{O}_{2}$ \\
\hline Control & $\mathrm{O}_{1}$ & - & $\mathrm{O}_{2}$ \\
\hline
\end{tabular}

Explanation:

$\mathrm{X}$ : Learning history using a inquiry-based local history

O1 : Problem pre-test of the experimental class and control

class

$\mathrm{O} 2$ : Problem post-test of the experimental class and control class

The Implementation of historical teaching and learning activities carried out in the experimental class and the control set the historical material for independence struggle in accordance with the model of learning that have been assigned to the second class. Here are the steps of classroom learning activities in experimental and control classes:

\section{Experimental Class Learning Activity}

Before the learning activities, teachers categorize students heterogeneously in 5 groups. The learning steps by using inquiry-based local history module as follows: (1) Aperception, at This phase, researchers prepare students to learn, explain the learning purpose, teachers give motivation and material history module in the learning process. Furthermore, researchers explain the $\mathrm{SK}, \mathrm{KD}$ and indicators. At this stage, the researchers start to introduce local history module opposition of Magelang youth defence Magelang in 1945 to students. (2) Exploration; at this stage the researchers began to explain some general things about learning by using learning inquiry model and give the problems that suitable to the materials for each group. The given problem related to "the history of the youth resistance in defending Indonesia indefendence in various areas" that can be implemented in the future now includes events Magelang youth resistance and their relevance for the life of society now includes events of Magelang youth resistance and the relevance for the society life (3) Elaboration; This phase, students demonstrate inquiry model starts with problem orientation / formulation that has been given, then the next step is hypotheses formulation. Teachers guide students to develop their opinions in hypotheses form to answer the question in the previous stage. (4) Confirmation; at this stage, the teachers guide students in the process of collecting sources, students also begin to ask questions about the data sources are suitable in the hypothesis. After students discuss and collect data, the next step is making a conclusion. Teachers guide students to present experimental results and 
Discussion and conduct a question and answer activity. Students present the discussion results then teachers guide students in drawing conclusions based on the discussion results. Teachers give students the conclusion strengthening of the material that has been studied (5) Closing; teachers give an evaluation with the test form to measure the understanding level of students about the material that has been studied.

\section{Control Class Learning Activity}

Before learning activities, teachers categorize students into 5 groups heterogeneously. Learning history in control class begins with learning steps as follows: (1) Recap; This phase researchers prepare students to learn, explain the learning purpose, teachers give motivation and materialpurpose. Then researchers explain the decree, KD and indicators. (2) Exploration; at this stage, the teacher explains the historical material of the independence struggle. Then, teachers give questions for students discussion about the material to each group. The given problem relates to "the historical of the youth resistance in defending the independence of Indonesia in various areas" that can be implemented at the present time including Magelang youth resistance and its relevance for society. (3) Elaboration; This stage, students discuss the question to the group (4) Confirmation; at this stage, the students present their discussion results. (5) Closing, the teacher asks the students to conclude the material that have just learned.

Based on Table 2. It can be seen that the average value of the experimental results and control class pretest, which mean each class are 65.71 and 67.70. While the results of the post-test showes that the average value of the post-test experimental class is higher than the control class. Which the average value of the experimental class is 79.64 with the difference value of 1.86 (medium) and a mean value of the control class 76.78. Therefore, after the use of implemented based local history module, there is an achievement incrase in the experimental and control class.

After a series of learning process conductes in both classes then perform post-test with the same questions in the experimental class and control class. The average Achievement of post-test results achievement experimental class and control class after being given a different treatment shows in image 1. Experimentation Class by inquiry based local history module has an average post-test better than the control class by conventional model.

However, the control class has not fullfiil the pass criteria for learning only tend to the concepts mastery and refer to the textbooks used. This causes the students can not develop the inquiry capability by search and find personal knowledge. Knowledge of student achievement in the control class is not optimal, it is influenced by the media has given teaching and monotonous learning model.

\section{CONCLUSIONS AND SUGGESTIONS}

Application of learning media is local history module Inquiry-based on the historical material of the struggle to defend independence to increase student achievement in one of SMA Muhammadiyah Magelang regency. The average class value through the use of inquiry-based local history modules on the learning achievement of 79.64. The effectiveness of the use of inquiry-based local history module obtained a value of 1.744 with a significance level of Tcount $=0.006<$ Ttable $=2.036$. Then $\mathrm{H} 0$ is rejected or there is a mean difference between experimental class and control class. It can be concluded that there are a positive and significant increase in the use of inquiry-based local history module in class. Therefore, the using of modules are effective in the learning, especially historical learning.

The suggestions related to this researches are: (1) to expand and deepen the effectiveness of using instructional media in improving student achievement, then for the next researcher can develop research related to learning media more innovative. (2) the parties interested in doing further research consider the possibility of other factors that influence learning styles of learners are seen not only from one point of view only. (3) further research can give benefit for research scientific research results to make

Table 2. Pre-test and post-test Learning Achievement Values

\begin{tabular}{ccccccc}
\hline & \multicolumn{2}{c}{ The Lowest value } & \multicolumn{2}{c}{ The highest value } & \multicolumn{2}{c}{ Avarage } \\
\hline Class & Control & Ekperimental & Control & Eksperimental & Control & Ekperimental \\
\hline Pre-test & 54 & 54 & 80 & 80 & 65,71 & 67,70 \\
\hline Post-test & 60 & 67 & 87 & 90 & 76,78 & 79,64 \\
\hline
\end{tabular}


learning process easier.

\section{REFERENCES}

Agung, Leo S. 2012. Pengembangan Model Pembelajaran Sejarah SMA Berbasis Pendidikan Karakter di Solo Raya. Jurnal Pendidikan dan Kebudayaan, 4(18), 412-426.

Ahmad A K H. 2007. Media Pembelajara. Makasar: Badan Penerbit Universitas Negeri Makassar.

Bretz, R. 1971. A Taxonomy of Communication Media Education Technology Publication. Englewood. Cliffs, N.J.

Cook, T.D dan Campbell. D.T. 1979. QuasiExperimentation: Design and Analysis Issue for Field Setting. USA: Hunghton Mifflin Co.

Creswell, J. W. 2010. Research Design: pendekatan kualitatif, kuantitatif, dan mixed. Yogyakarta: Pustaka Pelajar.

Diknas. 2004. Pedoman Umum Pengembangan Bahan Ajar. Jakarta: Ditjen Dikdasmen.

Eggen, P. D. dan Kauchak, D. P. 1996. Strategies for Teachers Teaching. Content and Thingking Skills Third Edition. Boston: Allyn and Bacon.

Gulo, W. 2002. Strategi Belajar Mengajar. Jakarta: Garamedia.

Hamalik, O. 1986. Media Pendidikan. Bandung. Alumni.

Hamzah B. Uno \& Nina L. 2011. Teknologi Komunikasi dan Informasi Pembelajaran. Jakarta: PT Bumi
Aksara, cet. 2.

Joyce, B \& Marsha W. 1980. Model of Teaching, fifth Edition. USA: Allyn and Bacon A Simon \& Scuster Company.

Kustandi \& Sutjipto. 2011. Media Pembelajaran Manual dan Digital. Bogor: Ghalia Indonesia.

Miarso, Y. 2004. Menyemai Benih Teknologi Pendidikan. Jakarta: Pustekkom Diknas.

Nata, A. 2009. Perspektif Islam tentang Strategi Pembelajaran. Jakarta: Kencana Prenada Media Group.

Piaget, J \& B Inhelder. 1971. Mental Imageryin Child. New York: Basic Books. .

Prastowo, A. 2011. Panduan Kretaif Membuat Bahan Ajar Inovatif. Yogyakarta: Diva Press.

Sanjaya, W. 2006. Stategi Pembelajaran Berorientasi Standar Proses Pendidikan. Jakarta: Kencana Prenada Grup.

Suryosubroto. 2009. Proses Belajar Mengajar di Sekolah. Jakarta: Rineka Cipta.

Trianto. 2009. Mendesain Model Pembelajaran InovtifProgresif. Jakarta: Kencana Prenada Media.

Widja, I Gede.1989. Panduan Pengajar Buku Sejarah Lokal suatu Perspektif dalam Pengajaran Sejarah. Jakarta: Proyek Pengembangan Lembaga Pendidikan Tenaga Kependidikan.

Wahyuni, S \& Leo A. 2013. Perencanaan Pembelajaran Sejarah. Yogyakarta: Ombak. 